\title{
Corpus callosum agenesis with interhemispheric cyst: a neuroimage to remember
}

\author{
Chaitanya Reddy, ${ }^{1}$ Deepanjan Bhattacharya, ${ }^{2}$ Priyanka Madaan, ${ }^{1}$ Lokesh Saini ${ }^{1}$
}

${ }^{1}$ Pediatric Neurology Unit, Department of Pediatrics, Post Graduate Institute of Medical Education and Research, Chandigarh, India ${ }^{2}$ Department of Pediatrics, Post Graduate Institute of Medical Education and Research, Chandigarh, India

\section{Correspondence to} Dr Lokesh Saini, drlokeshsaini@gmail.com

Accepted 3 July 2019

\section{DESCRIPTION}

An 18-month-old boy presented with global developmental delay since early infancy, with developmental age of 6 months without any dissociation along different domains. Vision and hearing were apparently normal. He was born to non-consanguineous parents at term with a smooth perinatal transition. There were no antenatal complications, although level II sonography was not done. He was hypotonic with an age-appropriate head circumference $(47 \mathrm{~cm})$. MRI of brain revealed a rare peculiar developmental malformation (callosal agenesis and an interhemispheric cyst communicating with lateral ventricles; figure 1). He was initiated on rehabilitative measures and parents were counselled regarding the prognosis.

Agenesis of corpus callosum (ACC) is a rare malformation reported in children with developmental delay. ${ }^{1}$ The clinical phenotype may vary from normalcy to epilepsy and intellectual disability, and depends on the nature of associated anomaliesinterhemispheric cyst, hydrocephalus, Dandy-Walker malformation or interhemispheric-fissure lipoma. ${ }^{23}$ Although the index child did not have any dysmorphism or associated anomalies, some children with ACC may have dysmorphic features such as hypertelorism, polysyndactyly, hallux duplication and so on. ${ }^{4}$ Barkovich classified ACC with interhemispheric cyst into type 1 cysts (diverticula of the lateral or third ventricles), and type 2 cysts (loculated cysts, not communicating with ventricles). ${ }^{5}$ Antenatal ultrasound is a good screening tool for identification of congenital cerebral malformations, which in our index child, was unfortunately not done. In

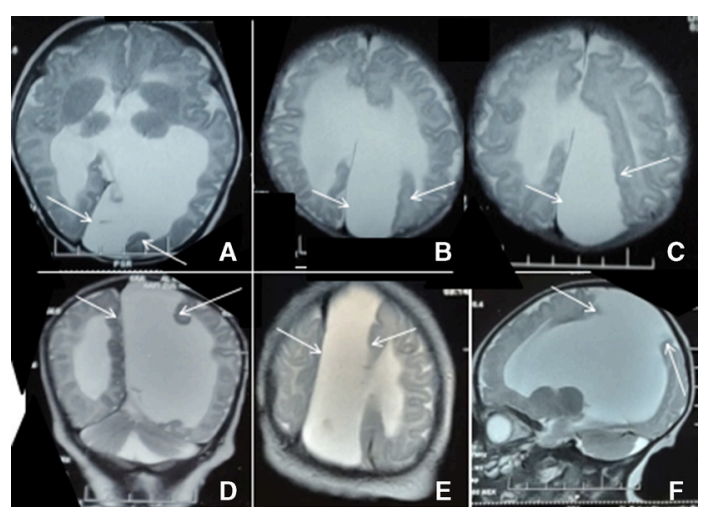

Figure 1 Axial $(A-C)$, coronal $(D, E)$ and sagittal $(F)$ T2weighted MRI of the brain showing an interhemispheric cyst (arrows) communicating with lateral ventricle (type 1 cyst) with non-visualisation of corpus callosum. the postnatal period, although ultrasound may be a useful screening tool, MRI is the modality of choice, where type 1 cysts are isointense to cerebrospinal fluid (CSF), while type 2 are hyperintense on both T1-weighted and T2-weighted images. In our index child, neuroimaging was suggestive of a type 1 cyst. This case highlights the importance of neuroimaging in children with developmental neurological disorders. The identification of this peculiar malformation is necessary since it clearly delineates the diagnosis and avoids unnecessary investigations. Also, in selected cases, these cysts may require shunting depending on their natural history. ${ }^{6}$

\section{Learning points}

- Neuroimaging is essential in developmental delays even if head size is normal, more so if neurological examination is abnormal.

- Association of interhemispheric cyst with callosal agenesis is rare.

- In cases of callosal agenesis with interhemispheric cyst, polymalformative syndromes such as acrocallosal syndrome should be considered if facial dysmorphism and digital anomalies are noted.

Contributors $D B, C R, P M$ and $L S$ were involved in patient care. $C R$ and DB prepared the initial draft of manuscript and reviewed the literature. PM and LS provided critical review of the manuscript and reviewed the literature, edited the final version of manuscript.

Funding The authors have not declared a specific grant for this research from any funding agency in the public, commercial or not-for-profit sectors.

Competing interests None declared.

Patient consent for publication Parental/guardian consent obtained.

Provenance and peer review Not commissioned; externally peer reviewed.

\section{REFERENCES}

1 Grogono JL. Children with agenesis of the corpus callosum. Dev Med Child Neurol 1968;10:613-6.

2 Byrd SE, Radkowski MA, Flannery A, et al. The clinical and radiological evaluation of absence of the corpus callosum. Eur J Radiol 1990;10:65-73.

3 Sztriha L. Spectrum of corpus callosum agenesis. Pediatr Neurol 2004;13:247-51.

4 Revanna KG, Rajadurai VS, Chandran S. Agenesis of the corpus callosum with interhemispheric cyst: clinical implications and outcome. BMJ Case Rep 2018;11:bcr-2018-227366.

5 Barkovich AJ, Simon EM, Walsh CA. Callosal agenesis with cyst: a better understanding and new classification. Neurology 2001;56:220-7

6 Lena G, van Calenberg F, Genitori L, et al. Supratentorial interhemispheric cysts associated with callosal agenesis: surgical treatment and outcome in 16 children. Childs Nerv Syst 1995;11:568-73. 
Images in...

Copyright 2019 BMJ Publishing Group. All rights reserved. For permission to reuse any of this content visit https://www.bmj.com/company/products-services/rights-and-licensing/permissions/

BMJ Case Report Fellows may re-use this article for personal use and teaching without any further permission.

Become a Fellow of BMJ Case Reports today and you can:

- Submit as many cases as you like

- Enjoy fast sympathetic peer review and rapid publication of accepted articles

Access all the published articles

Re-use any of the published material for personal use and teaching without further permission

Customer Service

If you have any further queries about your subscription, please contact our customer services team on +44 (0) 2071111105 or via email at support@bmj.com.

Visit casereports.bmj.com for more articles like this and to become a Fellow 